\title{
Communication
}

\section{Expression of Scytonemin Biosynthesis Genes under Alternative Stress Conditions in the Cyanobacterium Nostoc punctiforme}

\author{
Janine Bennett and Tanya Soule *(1)
}

check for

updates

Citation: Bennett, J.; Soule, T.

Expression of Scytonemin

Biosynthesis Genes under Alternative

Stress Conditions in the

Cyanobacterium Nostoc punctiforme.

Microorganisms 2022, 10, 427.

https://doi.org/10.3390/

microorganisms10020427

Academic Editors: Robert

Blankenship, Matthew Sattley and

Johannes F. Imhoff

Received: 24 December 2021

Accepted: 10 February 2022

Published: 12 February 2022

Publisher's Note: MDPI stays neutral with regard to jurisdictional claims in published maps and institutional affiliations.

Copyright: (C) 2022 by the authors. Licensee MDPI, Basel, Switzerland. This article is an open access article distributed under the terms and conditions of the Creative Commons Attribution (CC BY) license (https:/ / creativecommons.org/licenses/by/ $4.0 /)$.

\author{
Department of Biological Sciences, Purdue University Fort Wayne, Fort Wayne, IN 46805, USA; \\ Janine.Bennett@osumc.edu \\ * Correspondence: soulet@pfw.edu; Tel.: +1-260-481-0229
}

\begin{abstract}
The indole-alkaloid scytonemin is a sunscreen pigment that is widely produced among cyanobacteria as an ultraviolet radiation (UVR) survival strategy. Scytonemin biosynthesis is encoded by two gene clusters that are known to be induced by long-wavelength radiation (UVA). Previous studies have characterized the transcriptome of cyanobacteria in response to a wide range of conditions, but the effect on the expression of scytonemin biosynthesis genes has not been specifically targeted. Therefore, the aim of this study is to determine the variable response of scytonemin biosynthesis genes to a variety of environmental conditions. Cells were acclimated to white light before supplementation with UVA, UVB, high light, or osmotic stress for $48 \mathrm{~h}$. The presence of scytonemin was determined by absorbance spectroscopy and gene expression of representative scytonemin biosynthesis genes was measured using quantitative PCR. Scytonemin genes were up-regulated in UVA, UVB, and high light, although the scytonemin pigment was not detected under high light. There was no scytonemin or upregulation of these genes under osmotic stress. The lack of pigment production under high light, despite increased gene expression, suggests a time-dependent delay for pigment production or additional mechanisms or genes that may be involved in scytonemin production beyond those currently known.
\end{abstract}

Keywords: scytonemin; ultraviolet radiation; high light; cyanobacteria

\section{Introduction}

As phototrophic organisms, cyanobacteria must live in environments that are regularly exposed to solar ultraviolet radiation (UVR) [1]. Ultraviolet A radiation (UVA; 320-400 nm) is a major contributor to cell damage from solar energy [2] since more than $95 \%$ of solar UVR that reaches the Earth's surface is within the UVA range. The remainder of the UVR that reaches Earth comes from ultraviolet B radiation (UVB; $280-320 \mathrm{~nm}$ ) [3,4]. UVA indirectly damages DNA by interaction with cellular chromophores, which lead to the production of DNA-damaging reactive oxygen species. These reactive oxygen species also go on to damage other biomolecules, resulting in UVA as a major contributor to cell damage [2,5-8].

Cyanobacteria have evolved several defense strategies against UVA radiation [1,9-11]. One strategy employed is the production of the indole-alkaloid sunscreen pigment, scytone$\mathrm{min}$. When scytonemin accumulates extracellularly following UVR exposure, it intercepts harmful photons before they damage cellular machinery. Scytonemin remains stable in the presence of abiotic stressors and is reported to block up to $90 \%$ of UVR from entering the cell $[12,13]$. In addition to its protective ability against UVR, scytonemin shows antioxidant capabilities and nontoxicity [14-17].

Scytonemin biosynthesis is encoded by two conserved gene clusters in the cyanobacterium Nostoc punctiforme. The main biosynthetic cluster includes 18 genes (Npun_R1276 to Npun_R1259) regulated by an upstream two-component regulatory system (TCRS; Npun_F1278 and Npun_F1277) (Figure 1) [18-21]. Interestingly, the sensor kinase, Npun_ 
F1277, contains PAS/PAC domains [22]. In other studies, these domains have been shown to bind to small molecules in response to stimuli, such as light, oxygen, $\mathrm{pH}$, or salinity [23]. The other cluster of five genes (NpunF_5232 to NpunF_5236), known as the ebo cluster, is involved in precursor transport across the periplasm $[18,24]$. The downstream genes in the main gene cluster are involved in synthesizing amino acids, which are then utilized by the upstream genes scyA to scyC (Npun_R1276 to Npun_R1274) to synthesize specific scytonemin precursors [25-27]. Both gene clusters and the TCRS are highly conserved among closely related species of cyanobacteria, with the ebo cluster also occurring among diverse bacteria and algae $[18,24]$.

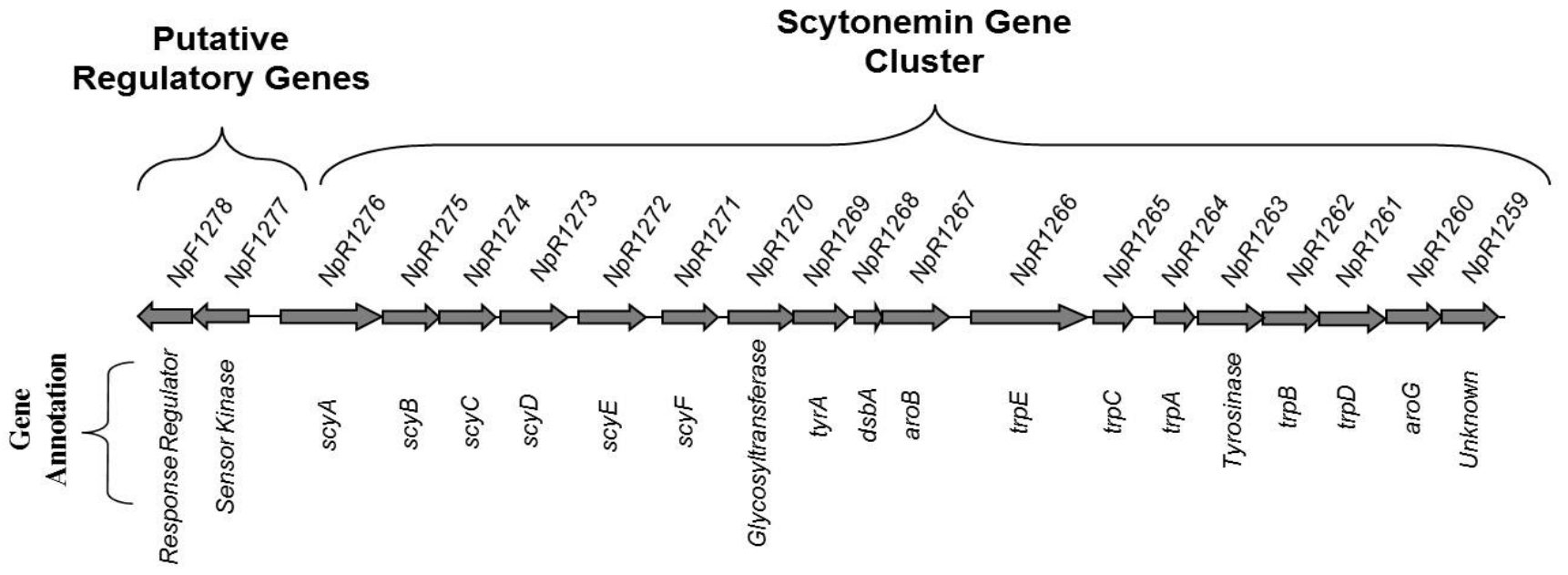

Figure 1. Main scytonemin biosynthetic gene cluster and regulatory genes in the N. punctiforme genome.

Although UVA alone can elicit the biosynthetic response, other studies have demonstrated that scytonemin induction can be enhanced by UVA supplemented with UVB, high light, and osmotic stress $[13,28,29]$. While these studies identified alternative stresses that can induce scytonemin biosynthesis, some were conducted in conjunction with UVA, while none of them were conducted at the gene expression level or in Nostoc punctiforme.

The objectives of this study are to evaluate the presence of scytonemin in Nostoc punctiforme and measure the transcriptional response of scytonemin biosynthetic genes in response to UVA, UVB, high light, and osmotic stress. It is widely accepted that UVA induces the production of scytonemin and a previous study revealed a synergistic or antagonistic effect, when cells were stressed with other environmental factors in conjunction with UVA [12,28]. Furthermore, expression of the main scytonemin biosynthetic gene cluster, the TCRS, and the ebo cluster have all been shown to increase in response to UVA stress [30,31]. Additionally, under short-term UVB and high light stress (20 to $60 \mathrm{~min}$ ), the TCRS responded with an increase in gene expression [31]. Given these previous studies, it is expected that the light-associated environmental conditions (UVA, UVB, and high light) will induce the expression of genes from both gene clusters, while a non-lightassociated condition, such as osmotic stress will downregulate these genes. To test this hypothesis, the expression of representative genes from each gene cluster were measured using quantitative-PCR following stress exposure. Genes scy $A$ and $\operatorname{trp} B$ were measured to represent the main biosynthetic cluster and $e b o E$ was measured for the $e b o$ gene cluster. A previous study showed that the main scytonemin gene cluster is transcribed as two main transcripts, the first starting with $s c y A$ and the downstream transcript starting with $\operatorname{trpE}$ [30]. Therefore, scy $A$ and $\operatorname{trp} B$ were chosen to record expression levels from each transcript. The eboE gene (Npun_F5233) is the fourth gene in the cluster. It was selected since it showed the strongest expression in response to UVA out of any of the ebo genes in a previous study [30].

This study adds value to the previous body of research since it directly connects various elements of what we know regarding scytonemin biosynthesis and how it relates 
to environmental conditions. For instance, there are studies that have focused on the induction of scytonemin under different conditions [28], others that have looked at the whole transcriptomic response to these conditions [32,33], and still others that connected scytonemin gene expression to only UVA stress [30]. To date, no single study has targeted the intersection of scytonemin biosynthesis, the associated gene expression response, and compared them under various conditions. Furthermore, any effort to mass produce scytonemin in a native host will need a thorough understanding of the regulatory mechanisms governing its synthesis to maximize efficiency. Overall, by identifying alternative ways to induce scytonemin at the gene expression level, this study will help us better understand the various ways that scytonemin may play a role in the cyanobacterial response to diverse environmental conditions.

\section{Materials and Methods}

\subsection{Strain, Culture Conditions, and Pigment Extraction}

Cultures of Nostoc punctiforme ATCC 29133 (PCC 73102; a gift from Ferran GarciaPichel) were grown under white light in sterile flasks containing the Allen and Arnon (AA/4) growth medium [34]. For high light and UVR exposure, N. punctiforme cells were filtered onto $90 \mathrm{~mm}$ polycarbonate membrane filters and the filters were placed floating on a nitrogen-free AA/4 medium in sterile glass dishes to allow for an even illumination and growth. All of the cultures remained under white light to acclimate and allow for initial growth. The conditions used for scytonemin induction studies were adapted from Dillon, Tatsumi, Tandingan, and Castenholz [28] and Soule, Garcia-Pichel, and Stout [30]: White light ( $40 \mu$ mols photons $\left.\mathrm{m}^{-2} \mathrm{~s}^{-1}\right)$ was supplemented with UVA ( $5 \mathrm{~W} \mathrm{~m}^{-2}$; continuous), UVB $\left(0.5 \mathrm{~W} \mathrm{~m}^{-2} ; 3 \mathrm{~h}\right.$ per day), or osmotic stress $\left(5 \mathrm{~g} \mathrm{NaCl} \mathrm{L}^{-1}\right.$; continuous) and high light was provided at a final intensity of $100 \mu$ mols photons $\mathrm{m}^{-2} \mathrm{~s}^{-1}$ (continuous). For UVB stress, transparent glass lids were replaced with a plastic film for optimal UVB penetration. Each stress condition was provided for $48 \mathrm{~h}$ since previous data showed that expression of the scytonemin biosynthetic genes peak after $48 \mathrm{~h}$ of continuous UVA exposure [30]. Control cultures for each experimental variable were grown under standard (white light) conditions in the absence of the stress. After the stress period, cells were vortexed off the filter into a sterile $\mathrm{AA} / 4$ medium and then concentrated by centrifugation, frozen in liquid nitrogen, and stored at $-80{ }^{\circ} \mathrm{C}$ until RNA processing.

To assess scytonemin pigment production following exposure, cells were opened by grinding with a glass mortar and pestle and scytonemin was extracted in 100\% acetone in the dark overnight. The presence of scytonemin was distinguished from other pigments by its ability to absorb light at $384 \mathrm{~nm}$ [12].

\subsection{Expression of Scytonemin-Associated Genes}

Total RNA was isolated from the cells using bead-beating and $\mathrm{LiCl}$ precipitation [35]. DNA was degraded in each sample with the Ambion TURBO DNA-free ${ }^{\mathrm{TM}}$ Kit (Life Technologies), according to the manufacturer's protocol. DNase-treated RNA ( $2 \mu \mathrm{g})$ was converted to cDNA using the Sensi-Fast cDNA Synthesis Kit (Bioline). Transcript levels of the scytonemin-associated genes, scyA (Npun_R1276), trpB (Npun_R1262), and eboE (Npun_F5233) were measured in triplicate with quantitative-PCR on a CFX Connect Real-Time PCR System (Bio-Rad Laboratories) using the iScriptTM Reverse Transcription Supermix for RT-PCR (Bio-Rad Laboratories) and primers from Soule, Garcia-Pichel, and Stout [30]. Samples were processed at $95^{\circ} \mathrm{C}$ for $3 \mathrm{~min}$, followed by 39 cycles at $95^{\circ} \mathrm{C}$ for $10 \mathrm{~s}$ and $55^{\circ} \mathrm{C}$ for $30 \mathrm{~s}$. The reference gene was Npun_R0035, which encodes for DNA gyrase, a housekeeping protein that has been used in similar studies $[30,31,36]$. Expression levels were normalized to those of the reference gene and the fold change between stressed and unstressed cells for all of the treatments was determined using the $\Delta \Delta \mathrm{Cq}$ formula for calculating normalized expression [37] in the CFX Manager software (Bio-Rad Laboratories). Statistical comparisons were conducted with triplicate biological replicate data 
using a student's $t$-test between the treated and untreated samples, with a $p$-value of $<0.05$ regarded as significant.

\section{Results}

\subsection{Scytonemin Production}

Scytonemin was extracted from the stressed cells to determine the relationship between scytonemin production and the expression of scytonemin biosynthetic genes. In response to $48 \mathrm{~h}$ of UVA and UVB exposure, scytonemin was produced by the cells (Figure 2). However, scytonemin was not produced in response to high light and osmotic stress using the same duration of exposure.

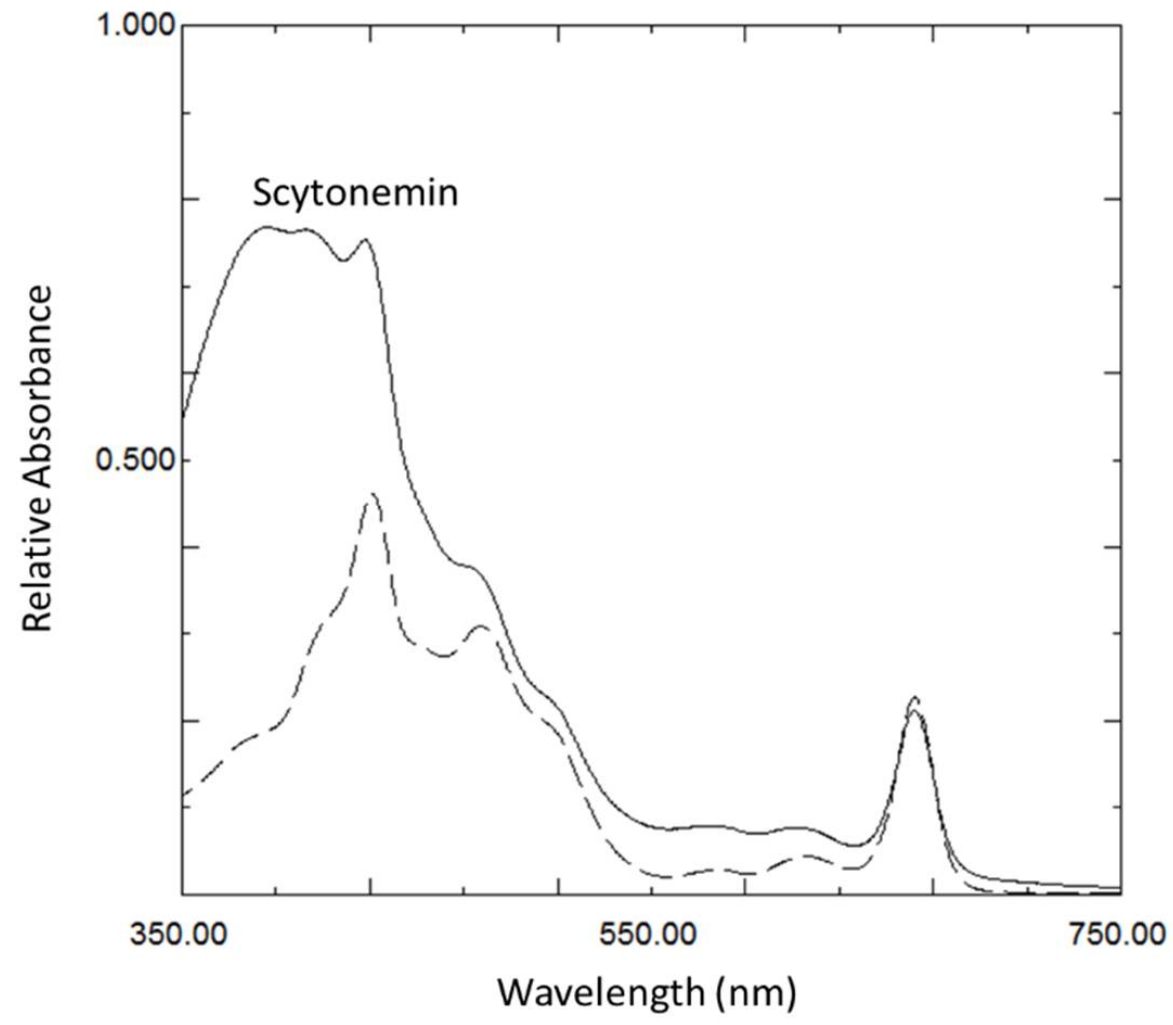

Figure 2. Representative absorption spectra of lipid-soluble pigments extracted from the cyanobacterium Nostoc punctiforme after exposure to UVA for $48 \mathrm{~h}$ with scytonemin (solid line) compared to high light for $48 \mathrm{~h}$ without scytonemin (dashed line). The strong absorption at $384 \mathrm{~nm}$ is indicative of scytonemin. Similar results were obtained for UVB (similar to the solid line) as well as high light and osmotic stress (similar to the dashed line).

\subsection{Gene Expression}

Experiments were conducted separately for each condition, with dedicated control experiments conducted in parallel for each condition. The gene expression analysis revealed the transcript abundance of scytonemin genes $s c y A, \operatorname{trp} B$, and $e b o E$ in response to each condition. Both $s c y A$ and $\operatorname{trp} B$ were upregulated in all of the conditions except for osmotic stress compared to the unstressed cells (Table 1). Interestingly, $\operatorname{trp} B$ had a stronger response for UVA, while scyA was stronger for UVB and high light stress. Osmotic-stressed samples showed a downregulation of $s c y A$ and $\operatorname{tr} p B$ in comparison to the unstressed samples. The $e b o E$ gene expression response was more variable. There were no significant changes in gene regulation for $e b o E$ in response to UVA compared to the untreated samples. However, in cells treated with UVB and osmotic stress, eboE was downregulated, and for those exposed to high light, it was upregulated. 
Table 1. Pigment production and transcript abundance of $s c y A, \operatorname{trp} B$, and $e b o E$ following $48 \mathrm{~h}$ of stress.

\begin{tabular}{|c|c|c|c|c|}
\hline Stress & Scytonemin & Gene & Fold Change & $p$-Value \\
\hline \multirow{3}{*}{ UVA } & \multirow{3}{*}{ Yes } & $\operatorname{scy} A$ & +26.05 & $0.049 *$ \\
\hline & & $\operatorname{trpB}$ & +77.53 & 0.039 * \\
\hline & & $e b o E$ & -1.63 & 0.278 \\
\hline \multirow{3}{*}{ UVB } & \multirow{3}{*}{ Yes } & scyA & +22.7 & $0.002 *$ \\
\hline & & $\operatorname{trpB}$ & +2.23 & 0.001 * \\
\hline & & $e b o E$ & -3.01 & 0.001 * \\
\hline \multirow{3}{*}{ High Light } & \multirow{3}{*}{ No } & $\operatorname{scy} A$ & +28.59 & $<0.001$ * \\
\hline & & $\operatorname{trpB}$ & +4.63 & $<0.001$ * \\
\hline & & $e b o E$ & +3.59 & $<0.001$ * \\
\hline \multirow{3}{*}{ Osmotic } & \multirow{3}{*}{ No } & scyA & -4.90 & $0.002 *$ \\
\hline & & $\operatorname{trp} B$ & -3.12 & 0.001 * \\
\hline & & $e b o E$ & -1.53 & 0.010 * \\
\hline
\end{tabular}

\section{Discussion}

Scytonemin is a highly effective molecule that plays an essential role in defending cyanobacteria against the harmful consequences of UVA exposure. It was hypothesized that the genes associated with sunscreen biosynthesis would be expressed in response to other environmental conditions. This was in part based on the broad ecological distribution of scytonemin-producing strains, as well as the previous literature $[12,28]$. The results mostly support the hypothesis by the upregulation of $s c y A$ and $\operatorname{trp} B$ genes in response to UVA, UVB, and high light. In response to osmotic stress, there was a downregulation in $s c y A$ and $\operatorname{trp} B$. In a previous study, osmotic stress in conjunction with UVA showed an inhibitory effect on scytonemin production [28]. Although the previous study did not include a transcriptional abundance parameter, it is reasonable to deduce that scytonemin genes were not upregulated.

The ebo gene cluster was studied since it is related to scytonemin biosynthesis, specifically to the export of scytonemin precursors across the periplasm [24]. The $e b o E$ gene showed a moderate upregulation when exposed to high light and a moderate downregulation under UVB, but overall showed a greater decrease in fold change reaction as compared to $s c y A$ and $\operatorname{trp} B$. This result is consistent with a previous study that showed that the expression of all the ebo genes followed the peak in the expression of the biosynthetic genes [30]. This temporal distinction between the biosynthetic genes and the ebo genes suggests that they play a post-biosynthetic role in the production of scytonemin, such as secretion or post-translation modification. Therefore, the role of the ebo cluster in export could explain the delayed gene expression response.

Although there was upregulation of the scytonemin genes in cultures treated with high light, scytonemin was not produced, in contrast to UVA and UVB stress. The differences in scytonemin production when comparing UVA, UVB, and high light suggest that other factors play a role in pigment production. One possibility is that the proteins involved in scytonemin biosynthesis are subject to post-translational modification and that high light does not regulate this process. While the post-translational regulatory mechanisms of these proteins are unknown, ScyF (Npun_R1271) contains a NHL domain subgroup (IPR013017) that could be involved in protein-protein interactions [27]. It is possible that this protein-protein interaction or others rely on post-translational modification. Alternatively, additional genes in the N. punctiforme genome could be involved in scytonemin biosynthesis, which are not expressed under high light. Still another possibility for the lack of pigment production under high light could be a time-dependent response for scytonemin production. The specific time point that transcripts and end products are measured is critical to the interpretation of the data, since transcript levels change rapidly and product synthesis can lag for days. In fact, scytonemin production has been shown to occur in response to high light over $99 \mu$ mols photons $\mathrm{m}^{-2} \mathrm{~s}^{-1}$ after 4 days of exposure, especially 
with the addition of blue light [12]. Therefore, the failure to detect scytonemin could be due to the fact that the stress period of 2 days was not sufficient for translation and enzyme activity to occur. Time was also shown to be a factor in a temporal study of expression that showed expression of the scytonemin biosynthetic genes after $48 \mathrm{~h}$ of UVA stress, while the ebo genes were not upregulated until $96 \mathrm{~h} \mathrm{[30].}$

\section{Conclusions}

The light-associated conditions effectively induced the expression of scytonemin genes, while osmotic stress did not. While this was expected, it was also surprising since scytonemin was not produced under high light stress. This can possibly be explained by unknown post-translational modifications or additional genes necessary for pigment production, which are not induced by high light. Alternatively, it could simply be due to differences in the temporal response between expression and biosynthesis. Regardless of the specific reason that high light did not result in pigment production, several possibilities exist that could be explored in future studies. These results emphasize the significance of studies targeting the intersection of the physiological response and specific gene expression response, rather than inferring this relationship from other studies. Overall, our results support previous studies, and based on the expression of genes under high light that did not result in pigment production, the data also suggest that additional mechanisms may be involved in the biosynthesis and regulation of this pigment.

Author Contributions: Conceptualization and methodology, T.S.; investigation, J.B.; resources, T.S.; writing—original draft preparation, J.B.; writing—review and editing, T.S.; funding acquisition, T.S. and J.B. All authors have read and agreed to the published version of the manuscript.

Funding: This research was funded by the Purdue University Fort Wayne Undergraduate Summer Research Support Program.

Institutional Review Board Statement: Not applicable.

Informed Consent Statement: Not applicable.

Data Availability Statement: The data presented in this study is available at https://users.pfw.edu/ soulet/pubs.html (accessed on 23 December 2021).

Conflicts of Interest: The authors declare no conflict of interest.

\section{References}

1. Castenholz, R.W.; Garcia-Pichel, F. Cyanobacterial responses to UV radiation. In Ecology of Cyanobacteria II; Whitton, B.A., Ed.; Springer: Dordrecht, The Netherlands, 2012; pp. 481-502.

2. Jagger, J. Solar-UV Actions on Living Cells; Praeger: New York, NY, USA, 1985.

3. Kasting, J.F. The Proterozoic Biosphere: A Multidisciplinary Study; Cambridge University Press: Cambridge, UK, 1992.

4. Garcia-Pichel, F. Solar ultraviolet and the evolutionary history of cyanobacteria. Orig. Life Evol. Biosph. 1998, $28,321-347$. [CrossRef]

5. Jiang, Y.; Rabbi, M.; Kim, M.; Ke, C.; Lee, W.; Clark, R.L.; Mieczkowski, P.A.; Marszalek, P.E. UVA generates pyrimidine dimers in DNA directly. Biophys. J. 2009, 96, 1151-1158. [CrossRef] [PubMed]

6. Van Baalen, C. The effects of ultraviolet radiation on a coccoid blue-green alga: Survival, photosynthesis, and photoreactivation. Plant Physiol. 1968, 43, 1689-1695. [CrossRef] [PubMed]

7. Donkor, V.A.; Häder, D.P. Effects of ultraviolet irradiation on photosynthetic pigments in some filamentous cyanobacteria. Aquat. Microbial. Ecol. 1996, 11, 143-149. [CrossRef]

8. Tyrell, R.M. UVA (320-380 nm) radiation as an oxidative stress. In Oxidative Stress: Oxidants and Antioxidants; Sies, H., Ed.; Academic Press: Berkeley, CA, USA, 1991; pp. 57-83.

9. Ehling-Schulz, M.; Scherer, S. UV protection in cyanobacteria. Eur. J. Phycol. 1999, 34, 329-338. [CrossRef]

10. Bebout, B.M.; Garcia-Pichel, F. UV-B-induced vertical migrations of cyanobacteria in a microbial mat. Appl. Environ. Microbiol. 1995, 61, 4215-4222. [CrossRef] [PubMed]

11. Canfield, L.M.; Forage, J.W.; Valenzuela, J.G. Carotenoids as cellular antioxidants. Proc. Soc. Exp. Biol. Med. 1992, 200, $260-265$. [CrossRef]

12. Garcia-Pichel, F.; Castenholz, R.W. Characterization and biological implications of scytonemin, a cyanobacterial sheath pigment. J. Phycol. 1991, 27, 395-409. [CrossRef] 
13. Garcia-Pichel, F.; Sherry, N.D.; Castenholz, R.W. Evidence for an ultraviolet sunscreen role of the extracellular pigment scytonemin in the terrestrial cyanobacterium Chlorogloeopsis sp. Photochem. Photobiol. 1992, 56, 17-23. [CrossRef]

14. Matsui, K.; Nazifi, E.; Hirai, Y.; Wada, N.; Matsugo, S.; Sakamoto, T. The cyanobacterial UV-absorbing pigment scytonemin displays radical-scavenging activity. J. Gen. Appl. Microbiol. 2012, 58, 137-144. [CrossRef] [PubMed]

15. Stevenson, C.S.; Capper, E.A.; Roshak, A.K.; Marquez, B.; Eichman, C.; Jackson, J.R.; Mattern, M.; Gerwick, W.H.; Jacobs, R.S.; Marshall, L.A. The identification and characterization of the marine natural product scytonemin as a novel antiproliferative pharmacophore. J. Pharmacol. Exp. Ther. 2002, 303, 858-866. [CrossRef]

16. Duan, Z.F.; Ji, D.N.; Weinstein, E.J.; Liu, X.Z.; Susa, M.; Choy, E.; Yang, C.; Mankin, H.; Hornicek, F.J. Lentiviral shRNA screen of human kinases identifies PLK1 as a potential therapeutic target for osteosarcoma. Cancer Lett. 2010, 293, 220-229. [CrossRef]

17. Evans, J.; Jones, A.C.; Blumenthal, E.; Soule, T. Anti-proliferation of melanoma cells and immune stimulation by the cyanobacterial indole-alkaloid scytonemin. Fine Focus 2021, 7, 54-63. [CrossRef]

18. Soule, T.; Palmer, K.; Gao, Q.; Potrafka, R.; Stout, V.; Garcia-Pichel, F. A comparative genomics approach to understanding the biosynthesis of the sunscreen scytonemin in cyanobacteria. BMC Gen. 2009, 10, 336-346. [CrossRef] [PubMed]

19. Soule, T.; Stout, V.; Swingley, W.D.; Meeks, J.C.; Garcia-Pichel, F. Molecular genetics and genomic analysis of scytonemin biosynthesis in Nostoc punctiforme ATCC 29133. J. Bacteriol. 2007, 189, 4465-4472. [CrossRef]

20. Naurin, S.; Bennett, J.; Videau, P.; Philmus, B.; Soule, T. The response regulator Npun_F1278 is essential for scytonemin biosynthesis in the cyanobacterium Nostoc punctiforme ATCC 29133. J. Phycol. 2016, 52, 564. [CrossRef]

21. Garcia-Pichel, F.; Lombard, J.; Soule, T.; Dunaj, S.; Wu, S.H.; Wojciechowski, M.F.; Giovannoni, S.J. Timing the evolutionary advent of cyanobacteria and the later great oxidation event using gene phylogenies of a sunscreen. mBio 2019, 10, e00561-19. [CrossRef] [PubMed]

22. Ashby, M.; Houmard, J. Cyanobacterial two-component proteins: Structure, diversity, distribution, and evolution. Microbiol. Mol. Biol. Rev. 2006, 70, 472-509. [CrossRef]

23. Ponting, C.P.; Aravind, L. PAS: A multifunctional domain family comes to light. Curr. Biol. 1997, 7, R674-R677. [CrossRef]

24. Klicki, K.; Ferreira, D.; Hamill, D.; Dirks, B.; Mitchell, N.; Garcia-Pichel, F.; Greenberg, E.P.; Burnap, R.; Preston, G.; Vermaas, W. The widely conserved $e b o$ cluster is involved in precursor transport to the periplasm during scytonemin synthesis in Nostoc punctiforme. mBio 2018, 9, e02266-18. [CrossRef]

25. Balskus, E.P.; Walsh, C.T. Investigating the initial steps in the biosynthesis of cyanobacterial sunscreen scytonemin. J. Am. Chem. Soc. 2008, 130, 15260-15261. [CrossRef]

26. Balskus, E.P.; Walsh, C.T. An enzymatic cyclopentyl[b]indole formation involved in scytonemin biosynthesis. J. Am. Chem. Soc. 2009, 131, 14648-14649. [CrossRef]

27. Ferreira, D.; Garcia-Pichel, F. Mutational Studies of Putative Biosynthetic Genes for the Cyanobacterial Sunscreen Scytonemin in Nostoc punctiforme ATCC 29133. Front. Microbiol. 2016, 7, 735. [CrossRef]

28. Dillon, J.G.; Tatsumi, C.M.; Tandingan, P.G.; Castenholz, R.W. Effect of environmental factors on the synthesis of scytonemin, a UV-screening pigment, in a cyanobacterium (Chroococcidiopsis sp.). Arch. Microbiol. 2002, 177, 322-331. [CrossRef] [PubMed]

29. Fleming, E.D.; Castenholz, R.W. Effects of periodic desiccation on the synthesis of the UV-screening compound, scytonemin, in cyanobacteria. Environ. Microbiol. 2007, 9, 1448-1455. [CrossRef] [PubMed]

30. Soule, T.; Garcia-Pichel, F.; Stout, V. Gene expression patterns associated with the biosynthesis of the sunscreen scytonemin in Nostoc punctiforme ATCC 29133 in response to UVA radiation. J. Bacteriol. 2009, 191, 4639-4646. [CrossRef] [PubMed]

31. Janssen, J.; Soule, T. Gene expression of a two-component regulatory system associated with sunscreen biosynthesis in the cyanobacterium Nostoc punctiforme ATCC 29133. FEMS Microbiol. Lett. 2016, 363, fnv235. [CrossRef]

32. Soule, T.; Gao, Q.; Stout, V.; Garcia-Pichel, F. The global response of Nostoc punctiforme ATCC 29133 to UVA stress, assessed in a temporal DNA microarray study. Photochem. Photobiol. 2013, 89, 415-423. [CrossRef] [PubMed]

33. Soule, T.; Ferreira, D.; Lothamer, J.; Garcia-Pichel, F. The independent and shared transcriptomic response to UVA, UVB and oxidative stress in the cyanobacterium Nostoc punctiforme ATCC 29133. Photochem. Photobiol. 2021, 97, 1063-1071. [CrossRef] [PubMed]

34. Allen, M.; Arnon, D.I. Studies on nitrogen-fixing blue-green algae. I. Growth and nitrogen-fixation by Anabaena cylindrica. Plant Physiol. 1955, 30, 366-372. [CrossRef] [PubMed]

35. Campbell, E.L.; Summers, M.L.; Christman, H.; Martin, M.E.; Meeks, J.C. Global gene expression patterns of Nostoc punctiforme in steady-state dinitrogen-grown heterocyst-containing cultures at single time points during the differentiation of akinetes and hormogonia. J. Bacteriol. 2007, 186, 5247-5256. [CrossRef] [PubMed]

36. Sorrels, C.M.; Proteau, P.J.; Gerwick, W.H. Organization, evolution, and expression analysis of the biosynthetic gene cluster for scytonemin, a cyanobacterial UV-absorbing pigment. Appl. Environ. Microbiol. 2009, 75, 4861-4869. [CrossRef] [PubMed]

37. Pfaffl, M.W. A new mathematical model for relative quantification in real-time RT-PCR. Nucleic Acids Res. 2001, $29,2002-2007$. [CrossRef] [PubMed] 